\title{
Awareness of International Financial Reporting Standards (IFRS): A study of Post- Graduate Students of Commerce \& Management in Kashmir
}

\author{
Aabida Akhter ${ }^{1}$ \\ ${ }^{1}$ (Research Scholar, Department of Business and Financial Studies, University of Kashmir, J\&K, India)
}

\begin{abstract}
The Institute of Chartered Accountants of India (ICAI) has announced its decision to adopt IFRS in India with effect from 1 April, 2011. The standards will have a significant impact on capital markets but students and investors know remarkably little about these standards. Many European countries shifted to IFRS as early as 2005. They are ahead of India in including IFRS in the curriculum for students. An understanding of Indian Generally Accepted Accounting Principles (GAAP) and IFRS standards is an urgent need for today's students. The commerce and management post- graduates are the future accounting professionals working in various companies s; thus, they must be aware about the newer concepts in accounting. In this backdrop, the study seeks to explore the degree of awareness about the newer concept of accounting standards called as the International Financial Reporting Standards (IFRS) amongst students of Commerce and Management in Kashmir.
\end{abstract}

Keywords: Indian GAAP; ICAI, IFRS, awareness, convergence

\section{Introduction}

Accounting has been integral function of micro and macro institutions. As an efficient tool of financial assessment, accounting is used in both households and corporate business units. It serves as a mode of communication to those who are interested in it .In India financial statements are prepared and guided by the accounting thought, regulations and standards issued and prescribed by Institute of Chartered Accountants of India (ICAI) in consultation with National Advisory committee on Accounting Standards (NACAS) . Propelled by the internationalization and globalization at an economic and organization level, the body of knowledge of accounting has expanded widely. Financial reporting is changing, accounting has always been a reactive service, changing and developing to meet the practical needs created by the environment in which it operates. These common set of ground rules enhance comparability and help reduce frauds and misrepresentation but they do not necessarily lead to the type of reports that would be most useful in internal decision making. For example if a company wants to sell land to finance a new store, they need to know the current market value of the land. However, GAAP requires that the land be stated at its original, historical cost in the financial reports. The more relevant data for decision making- the current market value is ignored under GAAP. In view of the various limitations of GAAP, most companies throughout the world are now communicating with their stakeholders using a different set of rules called International Financial Reporting Standards (IFRS). IFRS is a set of international accounting standards stating how particular types of transactions and other events should be reported in financial statements. The International Financial Reporting Standards (IFRSs) issued by the International Accounting Standards Board (IASB) are increasingly being recognised as Global Reporting Standards. The Institute of Chartered Accountants of India (ICAI) has proposed a plan for convergence with International Financial Reporting Standards (IFRS) for certain defined entities (listed entities, banks and insurance entities and certain other large-sized entities) with effect from accounting periods commencing on or after 1 April 2011. Statutory bodies/universities in India, who combine IFRS successfully into the course curriculum, will help students acquire significant competitive advantages in the career market. In India, courses in accounting and commerce are offered in management schools and universities where foundation, undergraduate, post-graduate and doctoral degree courses are taught. The two main professional bodiesInstitute of Charted Accountants of India (ICAI) and The Institute of Company Secretaries of India (ICSI), play a prominent role in incorporating international standards into accounting education. At present a Certificate Course on International Financial Reporting Standards is provided by ICAI. While the initial training for IFRS may come from regulators and international accounting firms, management schools and universities will eventually need to address these international standards. As future accounting professionals, commerce and management students must be aware new developments in this field. Knowledge of IFRS will make them understand better the information presented in financial statements of companies. It will also make them aware of expected changes in financial accounting and the reporting rules of the new standards, and understand the implications of such changes for business entities and users of financial statements. 


\section{Literature Review}

A number of researchers have tried assessing the awareness of newer concept of accounting and the impact of convergence of Indian accounting standards with the international financial reporting standards. KPMG India, 2009 conducted a survey in India and concluded that "implementation of IFRS requires changes to the regulatory environment, requires large pool of IFRS trained and experienced resources; and requires educating and communicating effectively with investors, analysts and Board of Directors. Samir S. Mogul International community has long back recognized the need for moving towards harmonization of the accounting standard across the globe. Obviously an individual country is always entitled to customize the existing international accounting Standards according to its specific needs. Among other advantages of harmonization of accounting standards, the two benefits which tops the list are (a) systematic review and evaluation of the performance of the multinational company having subsidiaries and associates in various countries wherein each country has its own set of GAAP and (b) It provides a level playing fields where no country is advantaged or disadvantaged because of its GAAP.' D'souza, Dolphy, 2009, "stated that regulatory approvals are must for the successful implementation of IFRS in India and so the Reserve Bank of India (RBI), Indian Banking Association (IBA) should align their policies according to the requirements of the international standards." The available literature on IFRS and its implementation covers the data from mainly European Union. Few studies have been carried out analyzing the data from other countries. With conversion to IFRS expected but not definite, many professors are troubled discerning the "how, when, and what" of incorporating IFRS into today's Accounting curriculum (Nilsen, 2008). This study identifies some problems in the accounting curricula of business information at the high school level and suggests improvements needed in the accounting textbooks. Working on the data of European firms, Armstrong et al (2010) found out a positive reaction to IFRS adoption events for firms with high quality pre adoption information, consistent with investors expecting net convergence benefits from IFRS adoption. In his study of 1084 European Union firms during the period of (1995-2006), Siqi Li (2010) concluded that on average, the IFRS mandate significantly reduces the cost of equity for mandatory adopters. He also suggested in his research that this reduction is present only in countries with strong legal enforcement and that increased disclosures and enhanced information comparability are two mechanisms behind the cost of equity reduction. Cai \& Wong (2010) in their study of global capital markets summarized that the capital markets of the countries that have adopted IFRS have higher degree of integration among them after their IFRS adoption as compared to the period before the adoption. Paananen \& Lin (2009) gave a contrary view to prior research that IFRS adoption ensures better quality of accounting information. Their analysis of German companies reporting showed that accounting information quality has worsened with the adoption of IFRS over time. They also suggested that this development is less likely to be driven by new adopters of IFRS but is driven by the changes of standards. Lantto \& Sahlstrom (2009) in their study of key financial ratios of companies of Finland found that the adoption of IFRS changes the magnitude of the key accounting ratios. The study also showed that the adoption of Fair Value Accounting rules and stricter requirements on certain Accounting issues are the reasons for the changes observed in Accounting Figures and financial ratios. Chand \& White (2007) in their paper on convergence of Domestic Accounting Standards and IFRS, demonstrated that the influence of Multinational Enterprises and large international accounting firms can lead to transfer of economic resources in their favour, wherein the public interests are usually ignored.Barth et al (2008) in their study of financial data of firms from 21 countries examined whether application of IAS/IFRS is associated with higher accounting quality. The findings of the study confirmed that firms applying IAS/IFRS evidence less earnings management, more timely loss recognition and more relevance of accounting numbers. The study also found out that the Firms applying IAS/IFRS experienced an improvement in accounting quality between the pre-adoption and post adoption period. Elena et al (2009) in their article dealing with the issues of convergence between US Generally Accepted Accounting Principles (GAAP) and IFRS were of the opinion that the adoption of IFRS in the USA undoubtedly would mark a significant change for many US companies. It would require a shift to a more principles-based approach, place for greater reliance on management (and auditor) judgment, and spur major changes in company processes and systems. Ali \& Ustundag (2009) in their paper on development process of Financial Reporting Standards around the World and its practical results in a developing country, Turkey. They observe that Turkey has encountered several complications in adaption of IFRS such as complex structure of the International standards, potential knowledge shortfalls and other difficulties in application and enforcement issues. Epstein (2009) in his article on Economic Effects of IFRS adoption emphasized on the fact that universal financial reporting standards will increase market liquidity, decrease transaction costs for investors, lower cost of capital and facilitate international capital formation and flows. Chen et al (2010) in their study of financial data of publicly listed companies in 15 member states of European Union (EU) before and after the full adoption of IFRS in 2005 found that the majority of Accounting Quality indicators improved after IFRS adoption in the EU. They found that there is less of managing earnings towards a target, a lower magnitude of absolute discretionary accruals and higher accruals quality. The study 
also showed that the improved accounting quality is attributable to IFRS, rather than changes in managerial incentives, institutional features of capital markets and general business environment. Patro and Gupta in their study found that the adoption of IFRS is a significant event for the business department in management schools and universities. In order to evaluate the amount and accuracy of student respondents' knowledge and/or information about IFRS, some keywords/concepts were selected. Respondents were asked about their understating of One Accounting World. About $50 \%$ of the students gave the correct answer as IFRS but $50 \%$ are still unaware of it. Again surprisingly $63 \%$ of the respondents are still unaware that ICAI has decided to adopt IFRS in India from 2011.

\section{Need Of The Study}

The introduction of IFRS represents a fundamental change in financial reporting, it said, adding planning for it, generating the necessary awareness, educating stakeholders and managing the required changes will take considerable management commitment and time to achieve a successful transition. Due to Globalization Foreign Capital has crept into the domestic market. The different disclosure requirements for listing purposes have hindered the free flow of capital. This has also led to failure in comparison of financial statements of companies of different countries. In order to have one accounting language many Countries around the globe have switched to IFRS and following their track ICAI also decided to implement IFRS in India from April 2011. The requirement is to have an understanding of the new accounting standards which are going to be implemented soon along with the awareness level of the employees and the clients of various companies. The post Graduate students of Commerce and Management in the near future would be working in the companies, thus there is a requirement that these students should be aware of this new concept of accounting. This paper tries to assess the degree of awareness among them and suggest whether there is a requirement of tutorials in this subject to be given to these students.

\section{Objectives Of The Study}

Following are the objectives of this paper:

1. To make a review of the studies conducted on the effects of convergence of domestic accounting standards and International Financial Reporting Standards (IFRS).

2. To find out the extent of awareness among the Post Graduate students of Commerce and Management in Kashmir about the new concept of International Financial Reporting Standards (IFRS) in the subject of accounting and the awareness regarding the process of convergence of accounting standards with IFRS in India.

\section{Research Methodology}

The type of research is descriptive. Convenience sampling has been adopted for the survey. Data has been collected from the primary source only mainly. To supplement the primary data, relevant secondary data has also been used which based on official records, committee reports, journals and books published on the subject. The survey has been conducted through the Questionnaire method. The questionnaires have been directly filled by the respondents. Almost all the questions are close-ended. The respondents are the students of commerce and management of Department of Business and Financial Studies, University of Kashmir, The Business School, University of Kashmir, Department of Management Studies, Islamic University of Science and Technology and the Department of Management Studies, Central University of Kashmir. The sample size selected was 350 but due to unwillingness and unawareness only 300 students responded to the questionnaire .The data collected through the questionnaires are presented in the following ways:

- Tables

- Pie charts

- Bar charts

- Column Charts

\section{Accounting Standards In India}

Accounting standards are rules (framed by an expert committee) in relation to recognition, measurement and disclosure of financial information in preparation of financial information. The basic objective of accounting standard is to standardize the accounting principles and the policies with a view to bring a common approach in preparation of financial statements.

Accounting Standards setting bodies in India- Following are the bodies responsible for setting up of Accounting Standards (AS).

> ICAI-: The Institute of Chartered Accountants of India on April 21, 1975 established Accounting Standard Board. The main function assigned to the ASB was to formulate accounting standards from time to time. However ICAI with ASB is carrying a good work of formulation and issuance of accounting standards. The 
Institute of Chartered Accountants of India (ICAI) is a statutory body established under the Chartered Accountants Act, 1949 (Act No. XXXVIII of 1949) for the regulation of the profession of chartered accountancy in India

$>$ Accounting Standards and SEBI:- Securities and Exchange Board of India was established in 1982 and it deals with the formulation of laws, by -laws, rules and amendments for the purpose of giving smooth and strong support to stock market. SEBI also focuses on protecting the interest of investors.

$>$ Accounting Standards and Income Tax Act 1961-: Section 145 of the income tax Act 1961 deals with the method of accounting to be adopted for computing the income under the head of "Profit and gains from business and Profession. The finance Act 1995 had amended section 145 w.e.f. from $1^{\text {st }}$ April 1997.

$>$ Accounting standards and company law-:Accounting Standards and Company bill 1997, proposed prescription of accounting standard by the central government in consultation with the National Advisory Committee on Accounting Standards (NACAS) established with sub- clause of the clause 415, companies bill 1997 defines Accounting Standards to mean standards of Accounting recommended by the Institute of Chartered Accountants of India constituted under the chartered Accountants Act 1949 as may be prescribed by the central government in consultation with NACAS, established under sub-section (1) of the clause 415, companies bill 1997

\section{Data Analysis And Discussion}

With the help of the questionnaire an attempt has been made to find out the extent of awareness regarding IFRS among Post Graduate Students of Commerce \& Management in Kashmir:

The respondents in the survey are mostly of the same age group and are pursuing their post-graduation from different universities in Kashmir Valley. Both male and female students were taken as respondents. Table 1 gives the description of the characteristics of the survey participants.

Table 1 : Respondent Characteristics

\begin{tabular}{|l|c|c|c|c|}
\hline & University of Kashmir & $\begin{array}{l}\text { Central university of } \\
\text { Kashmir }\end{array}$ & $\begin{array}{l}\text { Islamic University of Science and } \\
\text { Technology }\end{array}$ & Total \\
\hline $\begin{array}{l}\text { No. of } \\
\text { Respondents }\end{array}$ & 200 & 60 & 40 & 300 \\
\hline $\begin{array}{l}\text { No. of Female } \\
\text { respondents }\end{array}$ & 90 & 25 & 135 \\
\hline Course & M.Com/MFC/MBA & MBA & MBA \\
\hline
\end{tabular}

As per the table, total number of respondents is 300 . Majority of the respondents' i.e $67 \%$ (200 out of 300 ) are pursuing their courses in University of Kashmir. Out of the total respondents questioned 45\% (135 out of 300) are the female students.

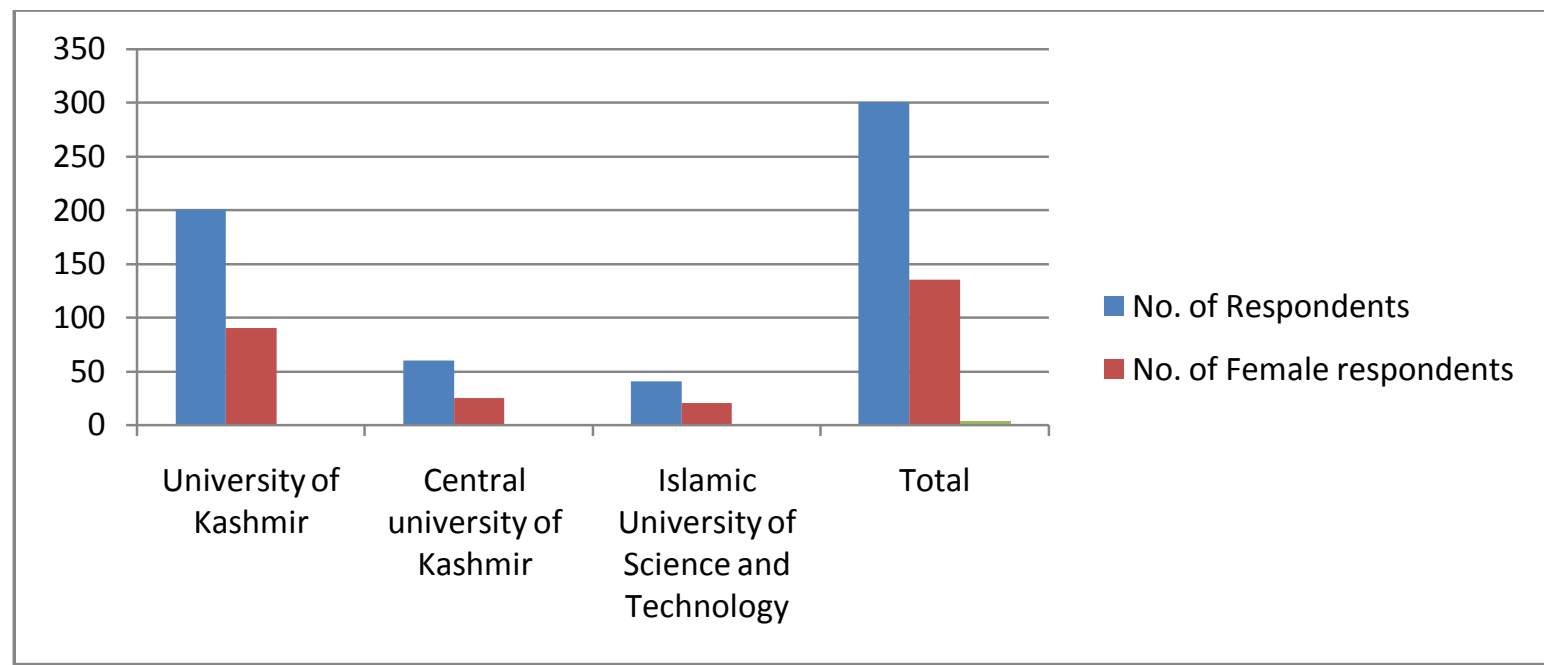

Analysis: The table shows that the majority of the respondents i.e., 67\% (200 out of 300) are pursuing their courses in University of Kashmir. Out of the total respondents questioned 45\% (135 out of 300) are the female students. 


\section{Questionnaire analysis - Awareness about New Accounting Standards (IFRS) ---}

In analyzing the questionnaire pie charts, bar charts and column charts have been used and results have been displayed in \% rather than counts . Following is the analysis of questionnaire:-.

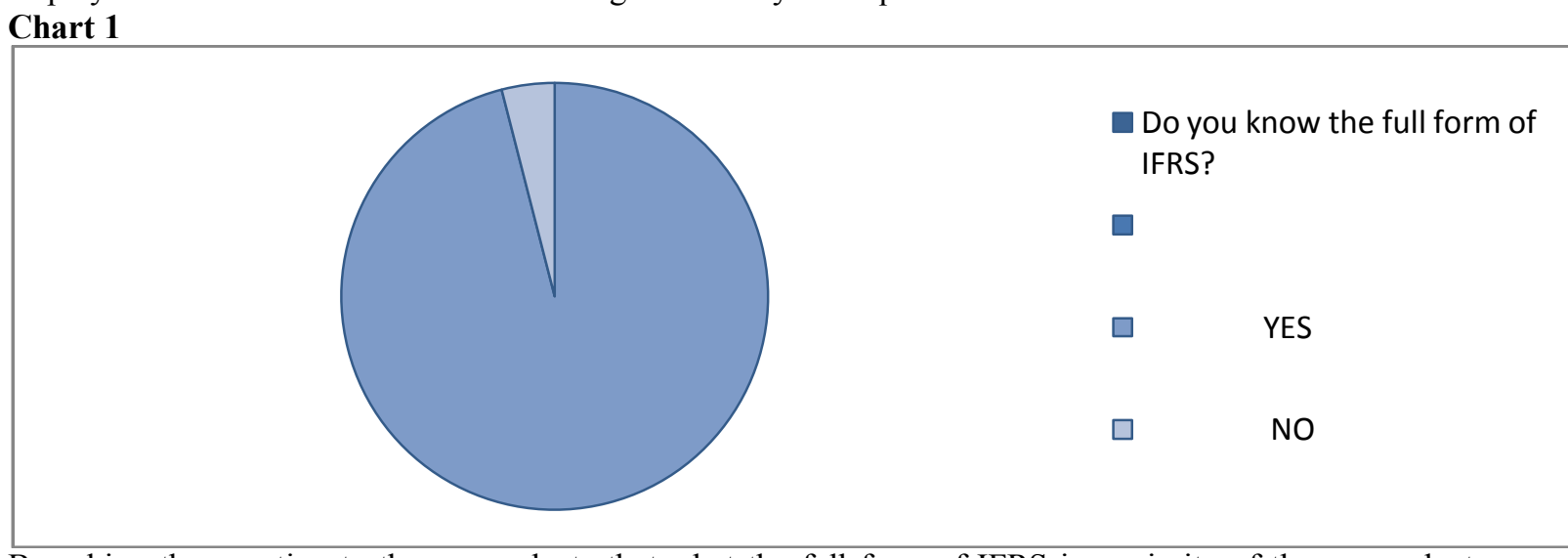

By asking the question to the respondents that what the full form of IFRS is, majority of the respondents are aware about it as above chart shows that $96 \%$ (i.e. 288 out of 300 )knew about it while $4 \%$ (i.e. 12 out of 300) are unaware of this .

Chart 2

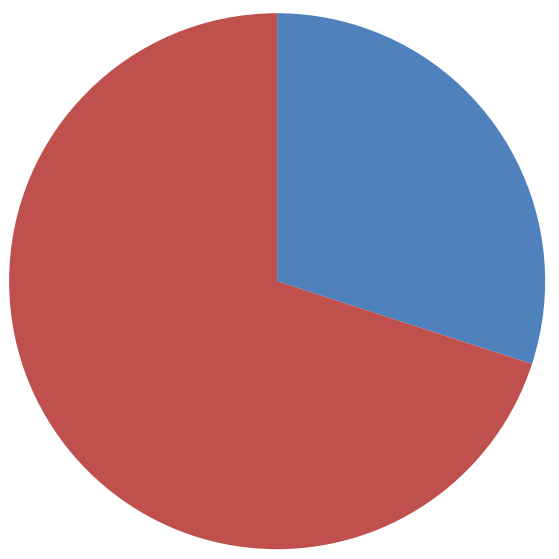

ICAI has announced the mandatory convergence of Indian Accounting Standards with IFRS from 1st April,2011: Yes

ICAI has announced the mandatory convergence of Indian Accounting Standards with IFRS from 1st April,2011: No

By asking the question to the respondents that when Institute of Chartered Accountants of India (ICAI) has announced the mandatory convergence of Indian Accounting Standards with IFRS, majority of the respondents are unaware about it, as above chart shows that $70 \%$ (i.e. 210 out of 300) did not know about it while only 30 $\%$ (i.e. 90 out of 300) are aware of this and responded rightly about it and answered it rightly that Institute of Chartered Accountants of India ( ICAI) has announced the mandatory convergence of Indian Accounting Standards with IFRS from $1^{\text {st }}$ April, 2011.

\section{Chart 3}




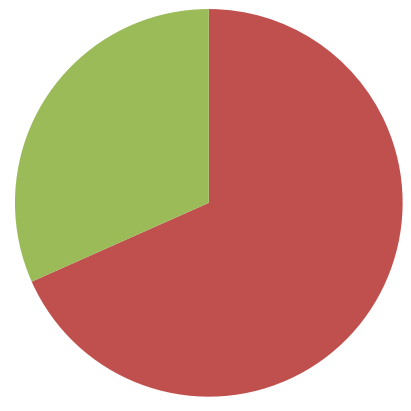

Do you know the number of IFRS effective presently?

YES

NO

By asking the question to the respondents about the number of IFRS effective presently, majority of the respondents are aware of it and responded positively and correctly about it ; as above chart shows that $68 \%$ (i.e. 205 out of 300 ) knew about it while $32 \%$ (i.e. 95out of 300) are unaware of this and did not respond rightly about it .

Chart

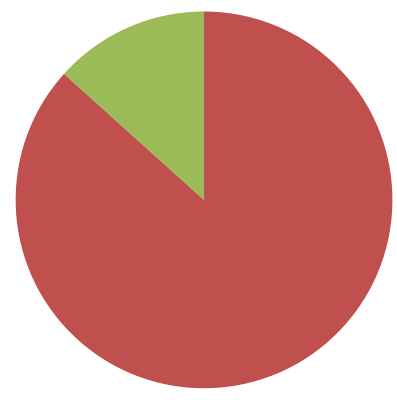

Accounting Standards and IFRS mean one and same thing?

yes

no

By asking the question to the respondents that IFRS and ASs mean one and the same thing, majority of the respondents are unaware of it and responded incorrectly about it ; as above chart shows that $87 \%$ (i.e. 260 out of 300) responded incorrectly about it while $13 \%$ (i.e. 40out of 300) are aware of this and responded rightly about it.

\section{Chart 5}

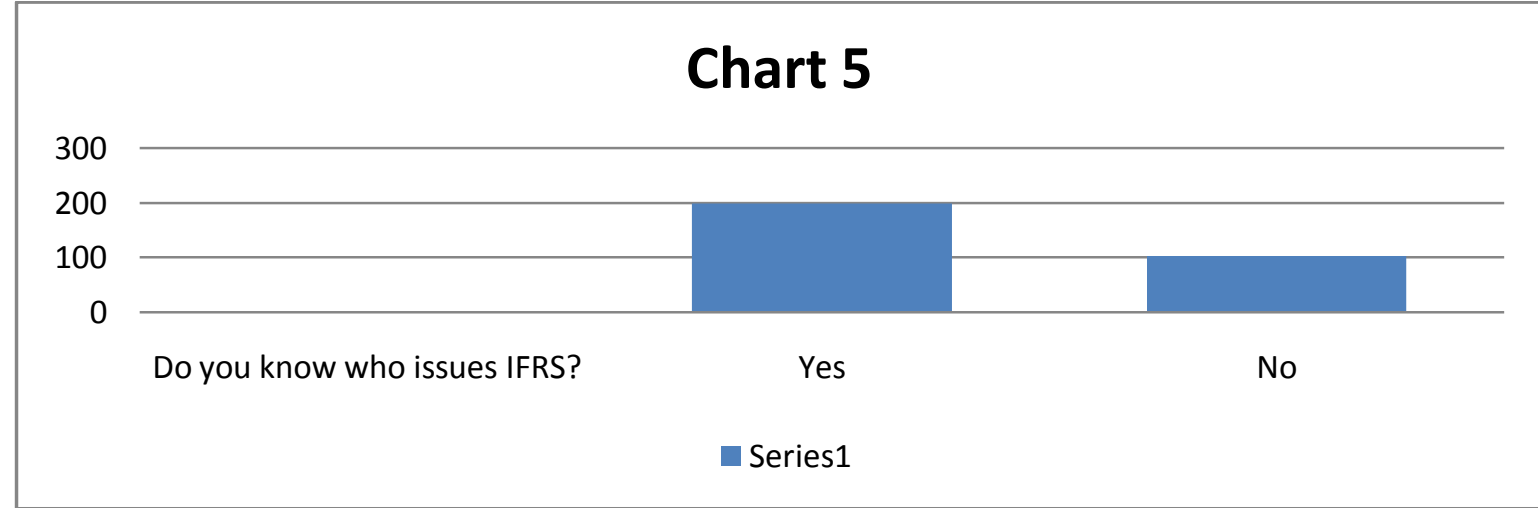

By asking the question to the respondents that who issues IFRS, majority of the respondents are aware of it and responded correctly about it; as above chart shows that $66 \%$ (i.e. 198 out of 300) responded correctly about it while $34 \%$ (i.e. 102out of 300) are unaware of this and responded incorrectly about it.

\section{Chart 6}




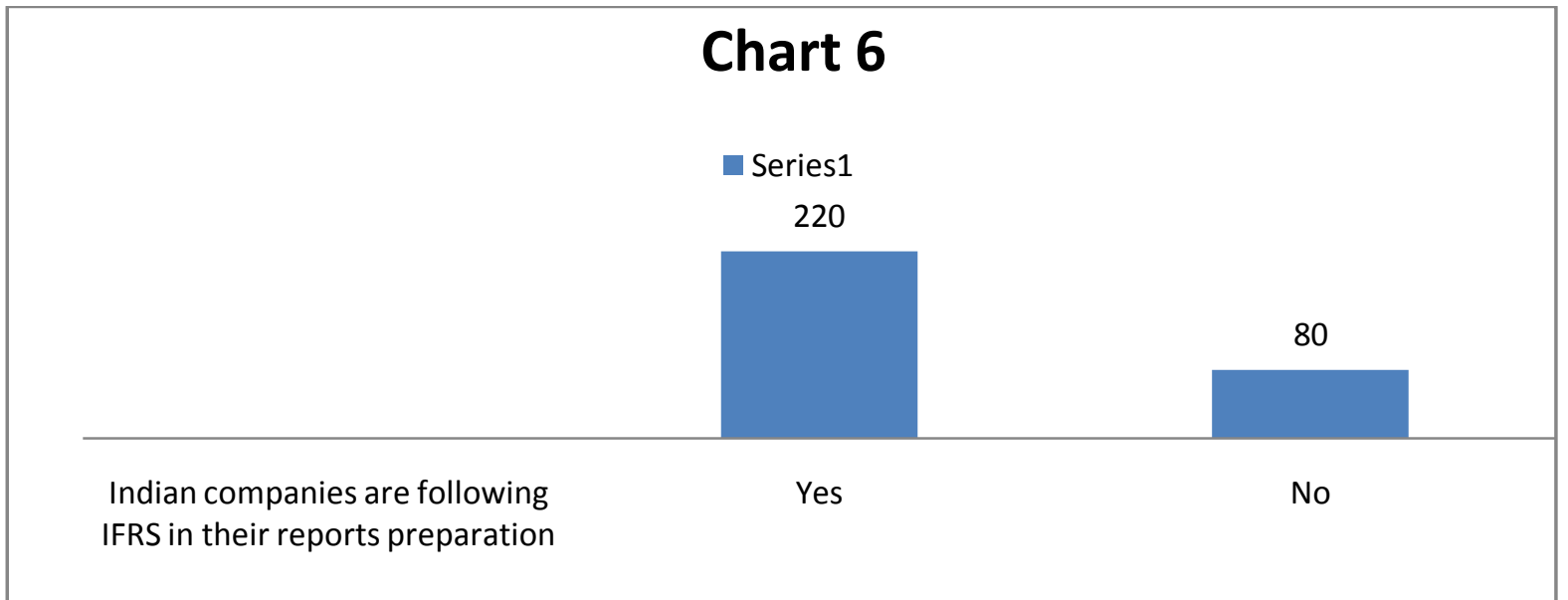

By asking the question to the respondents whether Indian companies are following IFRS in financial reporting, majority of the respondents are unaware of it and responded incorrectly about it; as above chart shows that 73 $\%$ (i.e. 220 out of 300 ) responded incorrectly about it while $27 \%$ (i.e. 80 out of 300 ) are aware of this and responded correctly about it.

\section{Chart 7}

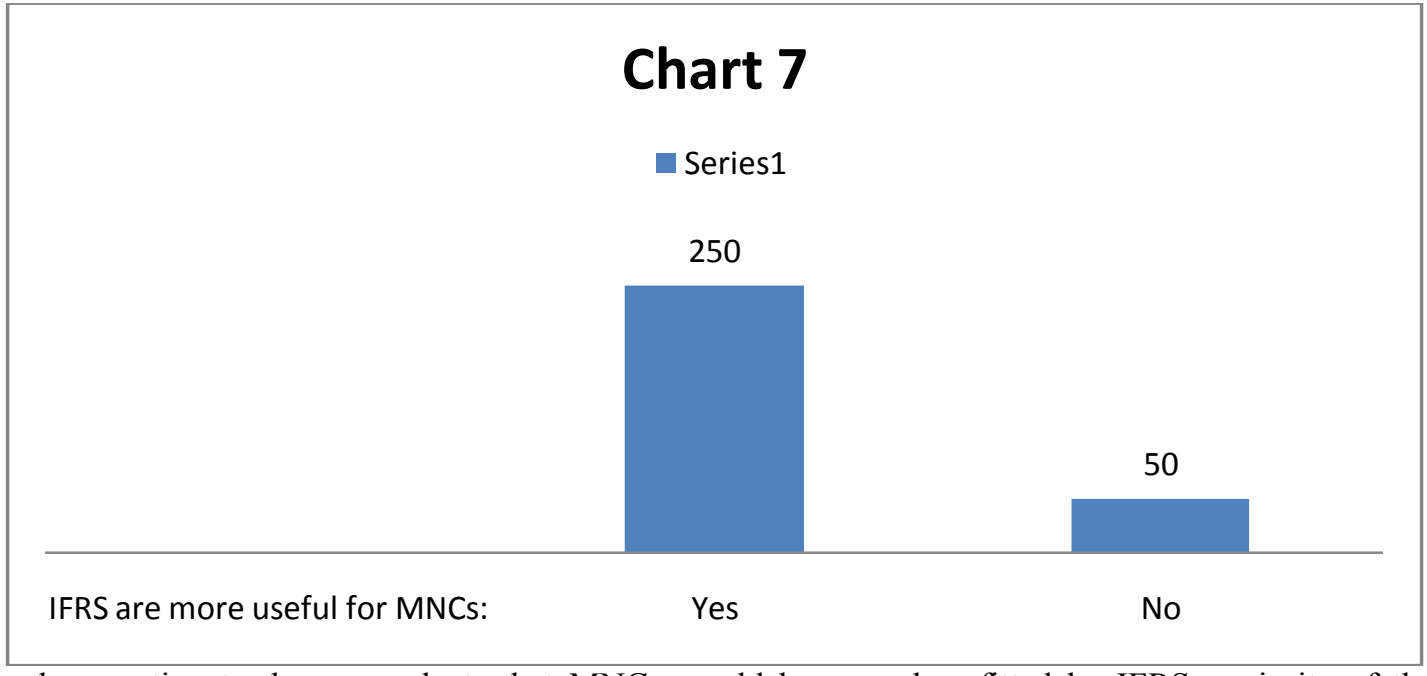

By asking the question to the respondents that MNCs would be more benefitted by IFRS, majority of the respondents are aware of it and responded correctly about it ; as above chart shows that $83 \%$ (i.e. 250 out of 300 ) responded correctly about it while $17 \%$ (i.e. 50 out of 300 ) are unaware of this and responded incorrectly about it.

\section{Chart 8}

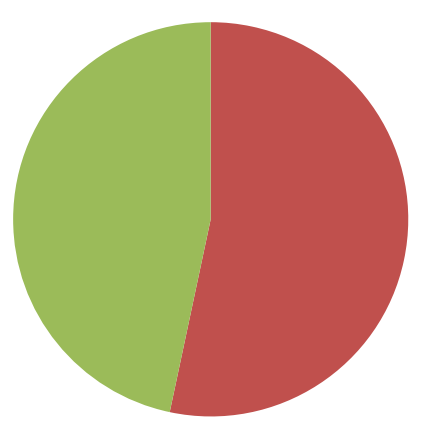

- Globalization has created the need for IFRS to bring in uniformity on global level:

Yes

No

In response to the question that Globalization has set an impetus for IFRS, we found that more than $50 \%$ of the respondents responded correctly; as above chart shows that $53 \%$ (i.e. 160 out of 300) responded correctly about it while $47 \%$ (i.e. 140 out of 300) are unaware of this and responded incorrectly about it. 


\section{Chart 9}

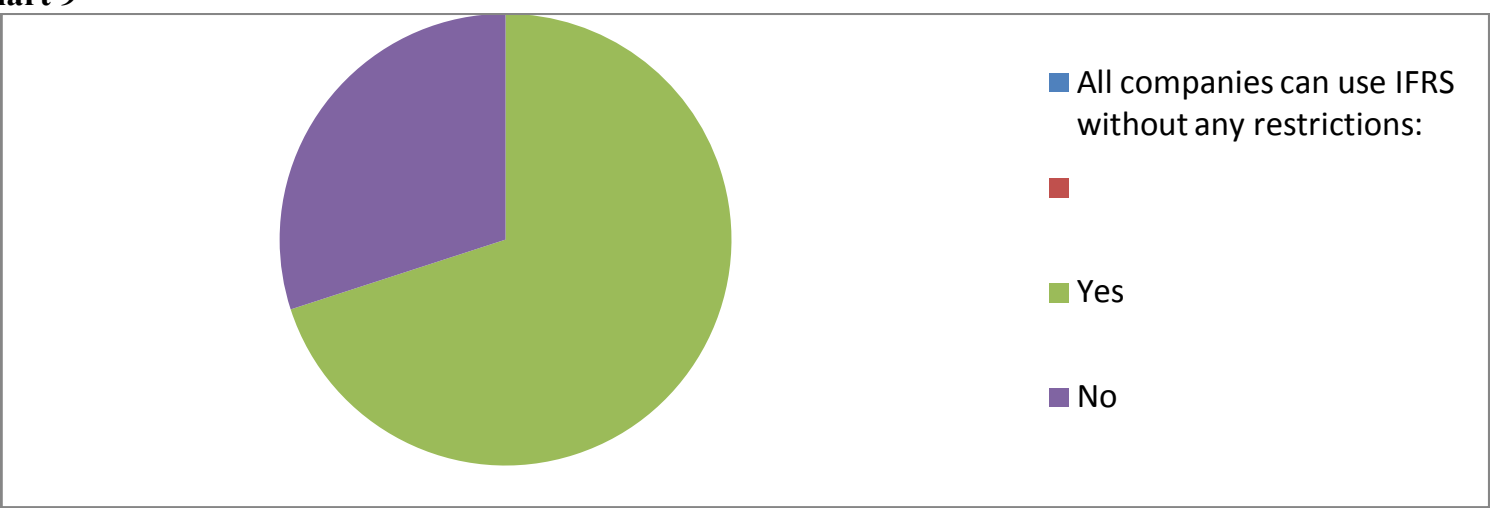

In response to the above question, we found that $50 \%$ of the respondents responded correctly ; as above chart shows that $53 \%$ (i.e. 150 out of 300 ) responded correctly about it while $50 \%$ (i.e. 150 out of 300 ) are unaware of this and responded incorrectly about it.

\section{Chart 10}

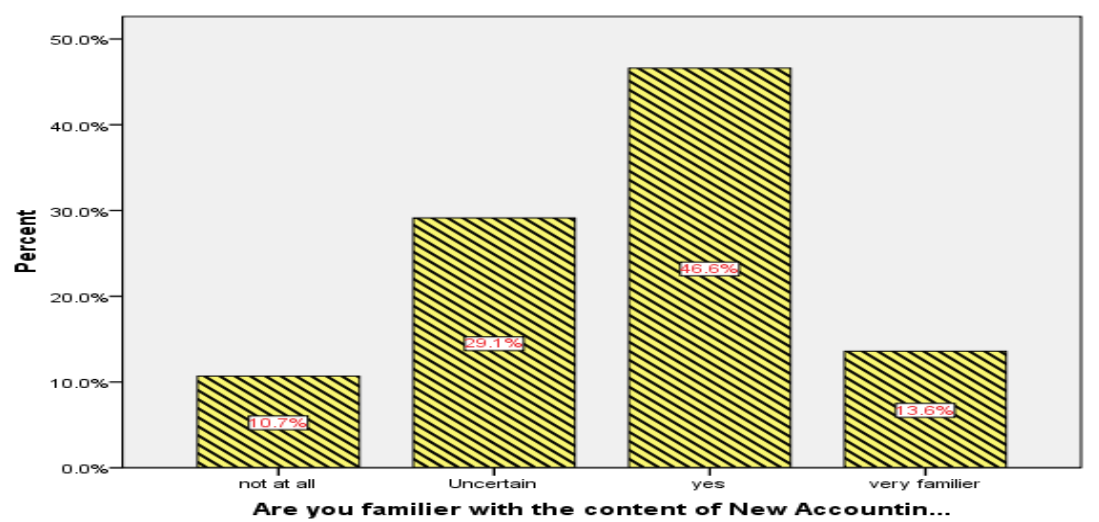

Though the majority of the respondents are aware about the implementation of IFRS in 2011 but when they were asked about the knowledge regarding content of IFRS very few people were very familiar. As per this chart $10.7 \%$ don't know about the contents of IFRS , $29.1 \%$ are uncertain , 46.6 know about IFRS and 13.6 are very familiar about the content of IFRS .

\section{Chart 11-}
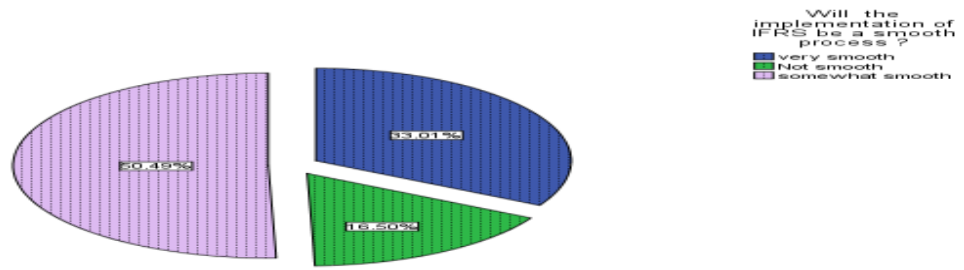

The implementation of IFRS will not be a very smooth process though the majority of people i.e. $50.49 \%$ say that implementation will be somewhat smooth. Only 33.01\% says that it will be very smooth rest 16.50 says that implementation will not at all be a smooth process. According to them the reason behind this is lack of knowledge, awareness, complexity of standard, lack of training etc. Still the efforts are made to make it somewhat smooth.

\section{Chart 12}



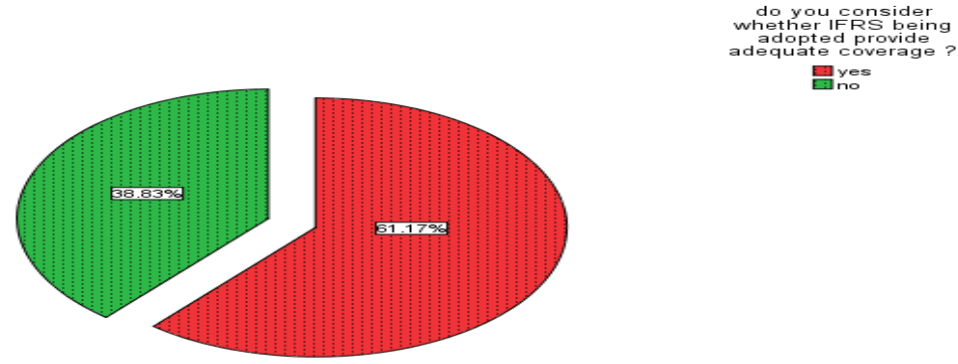

曷华的

As per the above chart majority of the respondents, 61\% (183 out of 300), say that IFRS provide adequate coverage and adoption of IFRS will bring harmony among the financial statements of various countries which is very important in the era of globalization. Whereas 39\% (117 out of 300) of the respondent say that IFRS does not provide full coverage and it should be modified and should incorporate some other standards too.

\section{Conclusions:}

The survey has given us an idea about the state of awareness of International Financial Reporting Standards (IFRS) among the post graduate students in Kashmir. Majority of the respondents are aware about some of the basic concepts of this new issue in accounting standards but it was also felt that a significant percentage of the respondents were not able to respond correctly. Moreover, majority of the respondents are not aware about the convergence of IFRS and the Indian accounting standards. Further, not all of the respondents are clear about the contents of IFRS. Clarity of content is very important if we want to make our accountants and auditors competitive in the global scenario. Many of the students do not know the full form of IFRS means they have no idea as to what these standards are all about. Some of the students said that there is no difference between Accounting Standards and the International Financial Reporting Standards, which again shows that they do not know what IFRSs are all about. Respondents also stated that they have no tutorials for any of the contemporary issue in any subject. Therefore, it was felt that there is a requirement of tutorials regarding the knowledge of this new issue in accounting standards among the post graduate students of Commerce and Management in Kashmir Valley. Courses related to contemporary issues in accounting and other relevant subjects should be delivered across all educational institutions so that students are made aware of the newer concepts of the subjects.

\section{References}

[1]. Jamil Khatri "What stakeholders need to do" "Head of Accounting Advisory Services; KPMG; IFRS convergence: the Hindu business line.

[2]. Samir S. Mogul ,Harmonization of Accounting Standards, CHARTERED ACCOUNTANT JANUARY 2003

[3]. Nilsen, Kim (2008), "On the Verge of an Accounting Revolution: How IFRS is Affecting Accounting Education," Journal of Accountancy

[4]. Survey by “Resources-Global Professionals D'souza, Dolphy August 2009

[5]. Bimal R. Bhatt, C.A, Accounting and Financial Polices, Practices, Standards \& Reporting, (Snow White Publication Pvt. Ltd , New Edition 2004-05)

[6]. Concept Paper on Convergence with IFRSs in India : ICAI

[7]. Cooper.W.W and Yuji Ijiri; Koehler's Dictionary for Accountants, Prentice Hall of India; New Delhi, 1984.

[8]. D.S Rawat, Students Guide to Accounting Standards (Taxman Publication $12^{\text {th }}$ edition 2008)

[9]. P.Krishna Prasanna ,Indian Accounting Standards and IFRS : A comparison, The Icfai Business School

[10]. Dr. A.L. Saini, International Financial Reporting Standards (IFRS), US GAAP,U.K GAAP and Indian GAAP, (Snow White Publication Pvt. .Ltd, 2005 )

[11]. Patro Archana and Gupta V. K., "Adoption of International Financial Reporting Standards (IFRS) in Accounting Curriculum in India - An Empirical Study" Procedia Economics and Finance 2 (2012) 227 - 236

\section{Websites:}

http://www.financialexpress.com

http://en.wikipedia.org

www.icai.org

www.iasb.org

www.moneycontrol.com 